D'ÁVILA, Gilmara Vanderlinde Medeiros. Averbação da reserva legal x Cadastro ambiental rural, avanço ou retrocesso?. Revista Eletrônica Direito e Política, Programa de Pós-Graduação Stricto Sensu em Ciência Jurídica da UNIVALI, Itajaí, v.10, n.1, edição especial de 2015. Disponível em: www.univali.br/direitoepolitica - ISSN 1980-7791.

\title{
AVERBAÇÃO DA RESERVA LEGAL X CADASTRO AMBIENTAL RURAL, AVANÇO OU RETROCESSO?
}

\author{
REGISTRATION OF THE LEGAL RESERVE X RURAL ENVIRONMENTAL \\ REGISTRY, FORWARD OR BACKWARD?
}

\section{Gilmara Vanderlinde Medeiros D'Avila ${ }^{1}$}

SUMÁRIO: Introdução. 1. Meio Ambiente. 2. Direito Ambiental. 3. Reserva Legal. 4. Cadastro Ambiental Rural. 5. Princípios norteadores do Direito Ambiental - Princípio da Vedação ao Retrocesso e Princípio da Informação. 6. O papel do Registro de Imóveis. Considerações finais. Referência das fontes citadas.

RESUMO: O presente trabalho tem como objetivo central analisar, juridicamente, se a revogação de averbação da reserva legal no registro de imóveis, trazida com o novo Código Florestal representou um avanço ou um retrocesso, na preservação ambiental.

Palavras-chave: Registro de Imóveis; Averbação da Reserva Legal; Cadastro Ambiental Rural - CAR; Direito Ambiental; Meio ambiente.

ABSTRACT: The present work is mainly aimed to analyze, legally, if the revocation of registration of the legal reserve in the property registry, brought in with the new Forest Code represented an advance or a setback in the environmental preservation.

Keywords: Real Estate Registry; Registration of the Legal Reserve; Rural Environmental Registry - CAR; Environmental Law; Environment.

\footnotetext{
${ }^{1}$ Mestranda em Ciência Jurídica pela UNIVALI/SC. Pós Graduada em Direito e Processo do Trabalho e em Direito Notarial e Registral. Bacharel em Direito pela UNIVALI/SC. Tabeliã de Notas e Protestos em Itajaí/SC. contato@cartorioitajai.com.br. Lattes: http://buscatextual.cnpq.br/buscatextual/visualizacv.do?id=K4813641Z0
} 
D'ÁVILA, Gilmara Vanderlinde Medeiros. Averbação da reserva legal x Cadastro ambiental rural, avanço ou retrocesso?. Revista Eletrônica Direito e Política, Programa de Pós-Graduação Stricto Sensu em Ciência Jurídica da UNIVALI, Itajaí, v.10, n.1, edição especial de 2015. Disponível em: www.univali.br/direitoepolitica - ISSN 1980-7791.

\section{INTRODUÇÃO}

Manter o equilíbrio ecológico do meio ambiente é tarefa que cabe ao Poder Público e à coletividade, conforme previsão expressa prevê do artigo 225 da Carta Constitucional vigente $-\mathrm{CF} / 1988$. O presente trabalho tem como objetivo central analisar, juridicamente, se a revogação da obrigatoriedade da averbação da reserva legal junto à matrícula do imóvel, no registro de imóveis, trazida com o novo Código Florestal ${ }^{2}$, parágrafo $4^{\circ}$. Do artigo 18 da Lei 12.651 de 2012, representou um avanço ou um retrocesso, em termos de preservação ambiental, analisando as principais disposições normativas relativas ao tema.

Primeiramente abordamos conceitos primordiais a análise do tema, como meio ambiente, direito ambiental e reserva legal, bem como, analisamos princípios ambientais - da vedação ao retrocesso e da informação - possivelmente violados com as alterações legais ocorridas.

Por fim, abordamos o importante papel desempenhado pelo registro de imóveis, de dar publicidade e prestar informações, inclusive em matéria ambiental.

Foi utilizado o Método Indutivo tanto na Fase de Investigação quanto como base da lógica do relato de seus resultados, operacionalizando as Técnicas do Referente, da Categoria, do Conceito Operacional e da Pesquisa Bibliográfica ${ }^{3}$.

\section{MEIO AMBIENTE}

Consoante artigo $3^{\circ}$ da Lei n. 6.938 de $31.08 .1981^{4}$, entende-se por meio ambiente o conjunto de condições, leis, influências e interações de ordem física,

\footnotetext{
2 Lei no 12.651 de 2012, Artigo 18, § $4^{\circ}$ O registro da Reserva Legal no CAR desobriga a averbação no Cartório de Registro de Imóveis, sendo que, no período entre a data da publicação desta Lei e o registro no CAR, o proprietário ou possuidor rural que desejar fazer a averbação terá direito à gratuidade deste ato. (Redação dada pela Lei no 12.727, de 2012).

3 PASOLD, Cesar Luiz. Prática da Pesquisa Jurídica - idéias e ferramentas úteis ao Pesquisador do Direito. 9 ed. Florianópolis: OAB-SC Editora co-edição OAB Editora, 2003. p.189 a 194.

${ }^{4}$ BRASIL. Presidência da República. Lei n. 6.938, de 31 de agosto de 1981. Dispõe sobre a Política Nacional do Meio Ambiente, seus fins e mecanismos de formulação e aplicação, e dá outras providências. Publicado no DOU de 2.9.1981. Disponível em: http://www.planalto.gov.br/ccivil_03/leis/l6938.htm , acesso em 29/09/2014.
} 
D'ÁVILA, Gilmara Vanderlinde Medeiros. Averbação da reserva legal x Cadastro ambiental rural, avanço ou retrocesso?. Revista Eletrônica Direito e Política, Programa de Pós-Graduação Stricto Sensu em Ciência Jurídica da UNIVALI, Itajaí, v.10, n.1, edição especial de 2015. Disponível em: www.univali.br/direitoepolitica - ISSN 1980-7791.

química e biológica, que permite, abriga e rege a vida em todas as suas formas.

O art. 20, I, da Lei Estadual Catarinense n. 5.793/80,5 que dispõe sobre a proteção e melhoria da qualidade ambiental e dá outras providências, conceitua meio ambiente como: "a interação de fatores físicos, químicos e biológicos que condicionam a existência de seres vivos e de recursos naturais e culturais".

Consoante Silva, o meio ambiente divide-se em três "aspectos", quais sejam:

a) artificial, formado pelo espaço urbano construído (espaço urbano fechado) e equipamentos públicos (espaço urbano aberto: áreas verdes, ruas, praças etc); b) cultural, formado pelo patrimônio histórico, arqueológico etc., e c) natural, ou físico, formado pela água, solo, flora etc, interação dos seres vivos em seu meio. ${ }^{6}$

No presente artigo, trataremos apenas de instituto de proteção ao último aspecto.

\section{DIREITO AMBIENTAL}

Como principal característica do Direito Ambiental está a sua perspectiva global. Considerando a forma pela qual os ecossistemas se relacionam e a vida se desenvolve em todo o planeta, é manifestamente impossível implementar uma tutela efetiva do meio ambiente restrita a determinado país ou território delimitado. ${ }^{7}$

A constituição de 1988 trouxe um capítulo próprio para a tutela do ambiente, tendo assim "constitucionalizado" a proteção ambiental, conforme ressalta

\footnotetext{
${ }^{5}$ SANTA CATARINA. Lei no 5.793, de 16 de outubro de 1980. Governo do Estado de Santa Catarina. Dispõe sobre a proteção e melhoria da qualidade ambiental e dá outras providências. Publicada no DO de 22/10/1980. Disponível em: http://200.192.66.20/alesc/PesquisaDocumentos.asp, acesso em 19/11/2013.

${ }^{6}$ SILVA, José Afonso da. Direito Ambiental Constitucional. 9a. Edição, São Paulo, Malheiros Editores, 2011, p. 21.

7 CRUZ, Paulo Márcio. Globalização, transnacionalidade e sustentabilidade [recurso eletrônico] /Paulo Márcio Cruz, Zenildo Bodnar ; participação especial Gabriel Real Ferrer ; org. e rev. Lucas de Melo Prado. - Dados eletrônicos. - Itajaí : UNIVALI, 2012. p. 165.
} 
D'ÁVILA, Gilmara Vanderlinde Medeiros. Averbação da reserva legal x Cadastro ambiental rural, avanço ou retrocesso?. Revista Eletrônica Direito e Política, Programa de Pós-Graduação Stricto Sensu em Ciência Jurídica da UNIVALI, Itajaí, v.10, n.1, edição especial de 2015. Disponível em: www.univali.br/direitoepolitica - ISSN 1980-7791.

Fensterseifer $^{8}$.

Estabelece o artigo 225 da Constituição que: "Todos têm direito ao meio ambiente ecologicamente equilibrado, bem de uso comum do povo e essencial à sadia qualidade de vida, impondo-se ao Poder Público e à coletividade o dever de defendê-lo e preservá-lo para as presentes e futuras gerações". 9

Já o artigo 186 preceitua que:

A função social é cumprida quando a propriedade rural atende, simultaneamente, segundo critérios e graus de exigência estabelecidos em lei, aos seguintes requisitos: I aproveitamento racional e adequado; II - utilização adequada dos recursos naturais disponíveis e preservação do meio ambiente; III - observância das disposições que regulam as relações de trabalho e IV - exploração que favoreça 0 bem-estar dos proprietários e dos trabalhadores. ${ }^{10}$

A Constituição passou a ser o grande vértice normativo da proteção jurídica do ambiente, de moda a irradiar a sua normatividade para todo 0 corpo legislativo infraconstitucional anterior e posterior à sua promulgação, bem como não recepcionando os textos anteriores no que estivessem em desacordo com as suas disposições. ${ }^{11}$

Registra Fensteirseifer que:

A formulação constitucional da proteção ambiental permite extrair a consagração de um "novo" direito (e dever) fundamental da pessoa humana, bem como a atribuição de uma tarefa ou fim constitucional de proteção ambiental ao

8 FENSTERSEIFER, Tiago. Direitos fundamentais e proteção do ambiente: a dimensão ecológica da dignidade humana no marco jurídico constitucional do estado socioambiental de direito. Porto Alegre: Livraria do Advogado Editora, 2008, p. 159.

${ }^{9}$ BRASIL. Presidência da República. CONSTITUIÇÃo DA REPÚBLICA FEDERATIVA DO BRASIL $\begin{array}{lcccccc}\text { DE 1988. Publicada no DOU DE } & \text { 5.10.1988. } & \text { Disponível } & \text { em: } \\ \text { http://www.planalto.gov.br/ccivil_03/constituicao/constituicaocompilado.htm } & \text { acesso } & \text { em }\end{array}$ 29/09/2014.

${ }^{10}$ BRASIL. Presidência da República. CONSTITUIÇÃo DA REPÚBLICA FEDERATIVA DO BRASIL DE 1988. Publicada no DOU DE 5.10.1988. Disponível em: http://www.planalto.gov.br/ccivil_03/constituicao/constituicaocompilado.htm ， acesso em 29/09/2014.

11 FENSTERSEIFER, Tiago. Direitos fundamentais e proteção do ambiente: a dimensão ecológica da dignidade humana no marco jurídico constitucional do estado socioambiental de direito. 2008, p. $160-161$. 
D'ÁVILA, Gilmara Vanderlinde Medeiros. Averbação da reserva legal x Cadastro ambiental rural, avanço ou retrocesso?. Revista Eletrônica Direito e Política, Programa de Pós-Graduação Stricto Sensu em Ciência Jurídica da UNIVALI, Itajaí, v.10, n.1, edição especial de 2015. Disponível em: www.univali.br/direitoepolitica - ISSN 1980-7791.

Estado brasileiro, o que, do ponto de vista jurídicoconstitucional, se caracteriza por ser uma composição extremamente importante para uma tutela constitucional efetiva do ambiente, lançando mão de dois flancos distintos para garantir uma tutela plena e integral, ou seja, tanto através da atuação do Estado como da mobilização da sociedade na defesa do ambiente.[... $]^{12}$

"O objeto da tutela jurídica não é tanto o meio ambiente considerado nos seus elementos constitutivos. O que o Direito visa a proteger é a qualidade do meio ambiente em função da qualidade de vida." 13

Levando em conta a Constitucionalização da proteção ambiental, registra Silva que,

a qualidade do meio ambiente transforma-se, assim, num bem ou patrimônio, cuja preservação, recuperação ou revitalização se tornaram um imperativo do Poder Público, para assegurar uma boa qualidade de vida, que implica boas condições de trabalho, lazer, educação, saúde, segurança enfim, boas condições de bem-estar do Homem e de seu desenvolvimento. ${ }^{14}$

Também o Código Civil Brasileiro reforça o cunho social e ambiental do atual direito de propriedade, ao estabelecer, no $\S 1^{\circ}$ do artigo 1228:

$\S 1^{0}$ - O direito de propriedade deve ser exercido em consonância com as suas finalidades econômicas e sociais e de modo que sejam preservados, de conformidade com o estabelecido em lei especial, a flora, a fauna, as belezas naturais, o equilíbrio ecológico e o patrimônio histórico e artístico, bem como evitada a poluição do ar e das águas. 15

Portanto, é imperativo que o Poder Público crie instrumentos para preservar o meio ambiente, bem como, efetivamente, os implemente, fiscalize e puna quem não obedecê-los. Dentre os instrumentos legais previstos, atentemos para a

12 FENSTERSEIFER, Tiago. Direitos fundamentais e proteção do ambiente: a dimensão ecológica da dignidade humana no marco jurídico constitucional do estado socioambiental de direito. 2008, p. 161.

${ }^{13}$ SILVA, José Afonso da. Direito Ambiental Constitucional. 2011, p. 83.

${ }^{14}$ SILVA, José Afonso da. Direito Ambiental Constitucional. 2011, p. 25.

${ }^{15}$ BRASIL. Presidência da República. Lei 10.406, de 10 de janeiro de 2002 . Institui o Código Civil. Publicado no DOU de 11.1.2002. Disponível em: http: //www.planalto.gov.br/ccivil_03/leis/2002//10406.htm, acesso em 29/09/2014. 
D'ÁVILA, Gilmara Vanderlinde Medeiros. Averbação da reserva legal x Cadastro ambiental rural, avanço ou retrocesso?. Revista Eletrônica Direito e Política, Programa de Pós-Graduação Stricto Sensu em Ciência Jurídica da UNIVALI, Itajaí, v.10, n.1, edição especial de 2015. Disponível em: www.univali.br/direitoepolitica - ISSN 1980-7791.

Reserva Legal, imposta a todos os imóveis rurais.

\section{RESERVA LEGAL}

A Constituição Federal preceitua, em seu artigo 186, que a função social da propriedade rural é cumprida quando atende, seguindo critérios e graus de exigência estabelecidos em lei, a requisitos certos, entre os quais o de 'utilização adequada dos recursos naturais disponíveis e preservação do meio ambiente'. ${ }^{16}$

A Lei 7.803/1989 criou a expressão reserva legal, para indicar a percentagem de floresta protegida nas propriedades privadas rurais. Referida lei impôs a obrigatoriedade da averbação da reserva legal na matrícula do imóvel, impedindo a alteração da sua destinação em caso de transmissão, alterando o Código Florestal vigente.

Definia o artigo $10, \S 20$, III, antigo Código Florestal ${ }^{17}$, que reserva legal é toda a área situada em posse ou propriedade rural, "excetuada a de preservação permanente, necessária ao uso sustentável dos recursos naturais, à conservação e reabilitação dos processos ecológicos, à conservação da biodiversidade e ao abrigo e proteção de fauna e flora nativas".

Consoante o novo Código Florestal, entende-se por reserva Legal a área localizada no interior de uma propriedade ou posse rural, delimitada nos termos do art. 12, com a função de assegurar o uso econômico de modo sustentável dos recursos naturais do imóvel rural, auxiliar a conservação e a reabilitação dos processos ecológicos e promover a conservação da biodiversidade, bem como o abrigo e a proteção de fauna silvestre e da flora nativa ${ }^{18}$.

${ }^{16}$ BRASIL. Presidência da República. CONSTITUIÇÃo DA REPÚBLICA FEDERATIVA DO BRASIL DE 1988. Publicada no DOU DE 5.10.1988. Disponível em: http://www.planalto.gov.br/ccivil_03/constituicao/constituicaocompilado.htm ， acesso em $18 / 11 / 2013$.

${ }^{17}$ Lei 4.771 de 1965. BRASIL. Presidência da República. Lei n. 4.771, de 15 de setembro de 1965. Institui o Código Florestal. Publicada no D.O.U de 16.9.1965. Disponível em: https://www.planalto.gov.br/ccivil_03/LEIS/L4771.htm, acesso em 29/09/2014.

18 BRASIL. Presidência da República. Lei 12.651 de 25 de maio de 2012. Publicada no DOU DE 28.05.2012. Disponível em: http://www.planalto.gov.br/ccivil_03/_Ato2011- 
D'ÁVILA, Gilmara Vanderlinde Medeiros. Averbação da reserva legal x Cadastro ambiental rural, avanço ou retrocesso?. Revista Eletrônica Direito e Política, Programa de Pós-Graduação Stricto Sensu em Ciência Jurídica da UNIVALI, Itajaí, v.10, n.1, edição especial de 2015. Disponível em: www.univali.br/direitoepolitica - ISSN 1980-7791.

Percebe-se que o novo Código Florestal, ao não mais excetuar da área de reserva legal as áreas de preservação permanente, como fazia o diploma anterior, propiciou flagrante flexibilização da proteção ambiental.

"A Reserva Legal é a parcela do terreno com cobertura de vegetação nativa, destinada ao uso sustentável dos recursos naturais e à conservação da biodiversidade, não passível de desmatamento ou intervenção." 19

O percentual a ser preservado como reserva legal varia de um mínimo de $20 \%$ e atinge um máximo de até $80 \%$, nos imóveis localizados em área de florestas na Amazônia.

Portanto, a Reserva Legal revela-se instrumento de grande importância na manutenção da qualidade de vida e no equilíbrio ecológico. Objetiva ela restringir o exercício da posse e da propriedade em delimitadas porções de terra, visando salvaguardar uma conservação mínima do meio ambiente.

Consoante reconheceram os Tribunais, trata-se a reserva legal de um ônus real incidente sobre o imóvel:

AMBIENTAL. PROCESSUAL CIVIL. OMISSÃO INEXISTENTE. INSTITUIÇÃO DE ÁREA DE RESERVA LEGAL. OBRIGAÇÃO PROPTER REM E EX LEGE. SÚMULA 83/STJ. APLICAÇÃO DO ART. 68 DO NOVO CÓDIGO FLORESTAL. IMPOSSIBILIDADE. DESRESPEITO AOS PERCENTUAIS EXIGIDOS PARA A ÁREA DE RESERVA LEGAL. VERIFICAÇÃO. IMPOSSIBILIDADE. SÚMULA 7/ST]. DEVER DE AVERBAÇÃO DA RESERVA LEGAL. IMPOSIÇÃO. (...) 1. (...) 2. A jurisprudência desta Corte está firmada no sentido de que os deveres associados às APPs e à Reserva Legal têm natureza de obrigação propter rem, isto é, aderem ao título de domínio ou posse, independente do fato de ter sido ou não o proprietário o autor da degradação ambiental. Casos em que não há falar em culpa ou nexo causal como determinantes do dever de recuperar a área de preservação permanente. 3. Este Tribunal tem entendido que

2014/2012/Lei/L12651.htm, acesso em 29/09/2014.

19 VILARINHO, Renata. ÁREAS DE PRESERVAÇÃo. Cadastro Ambiental Rural traz a tão esperada simplificação. Disponível em: http://www.conjur.com.br/2014-mai-14/renata-vilarinho-cadastroambiental-rural-traz-tao-esperada-simplificacao, acesso em 25/09/2014. 
D'ÁVILA, Gilmara Vanderlinde Medeiros. Averbação da reserva legal x Cadastro ambiental rural, avanço ou retrocesso?. Revista Eletrônica Direito e Política, Programa de Pós-Graduação Stricto Sensu em Ciência Jurídica da UNIVALI, Itajaí, v.10, n.1, edição especial de 2015. Disponível em: www.univali.br/direitoepolitica - ISSN 1980-7791.

a obrigação de demarcar, averbar e restaurar a área de reserva legal nas propriedades rurais configura dever jurídico (obrigação ex lege) que se transfere automaticamente com a mudança do domínio, podendo, em consequência, ser imediatamente exigível do proprietário atual. (...) Agravo regimental improvido. (STJ, AgRg no REsp 1367968/SP, Rel. Ministro HUMBERTO MARTINS, SEGUNDA TURMA, julgado em 17/12/2013, DJe 12/03/2014). ${ }^{20}$

ADMINISTRATIVO. MEIO AMBIENTE. ÁREA DE RESERVA LEGAL EM PROPRIEDADES RURAIS: DEMARCAÇÃO, AVERBAÇÃOO E RESTAURAÇÃO. LIMITAÇẪO ADMINISTRATIVA. OBRIGAÇÃO EX LEGE E PROPTER REM, IMEDIATAMENTE EXIGÍVEL DO PROPRIETÁRIO ATUAL. 1. Em nosso sistema normativo (Código Florestal - Lei 4.771/65, art. 16 e parágrafos; Lei 8.171/91, art. 99), a obrigação de demarcar, averbar e restaurar a área de reserva legal nas propriedades rurais constitui (a) limitação administrativa ao uso da propriedade privada destinada a tutelar o meio ambiente, que deve ser defendido e preservado 'para as presentes e futuras gerações' (CF, art. 225). Por ter como fonte a própria lei e por incidir sobre as propriedades em si, (b) configura dever jurídico (obrigação ex lege) que se transfere automaticamente com a transferência do domínio (obrigação propter rem), podendo, em conseqüência, ser imediatamente exigível do proprietário atual, independentemente de qualquer indagação a respeito de boa-fé do adquirente ou de outro nexo causal que não o que se estabelece pela titularidade do domínio. (STJ, REsp 1.179.316/SP, Rel. Ministro Teori Albino Zavascki, Primeira Turma, julgado em 15.6.2010, DJe de 29.6.2010. $)^{21}$

Portanto, resta pacífico nos tribunais que, a obrigação de demarcar, de restaurar e até a de averbar a área de reserva legal nas propriedades rurais representa um dever jurídico (uma obrigação ex lege) que se transfere com a transferência do domínio de forma automática, com o que, pode ser imediatamente exigível do proprietário atual.

https://ww2.stj.jus.br/processo/revista/documento/mediado/?componente=ATC\&sequencial $=3320$ 8858\&num_registro $=201200049293 \&$ data $=20140312 \&$ tipo $=5 \&$ formato $=P D F, \quad$ acesso em $16 / 12 / 2014$.

$21 \quad$ Disponível

em:

https://ww2.stj.jus.br/processo/revista/documento/mediado/?componente=ATC\&sequencial $=1068$ 2819\&num_registro $=200902357386 \&$ data $=20100629 \&$ tipo $=5 \&$ formato $=P D F, \quad$ acesso em $16 / 12 / 2014$. 
D'ÁVILA, Gilmara Vanderlinde Medeiros. Averbação da reserva legal x Cadastro ambiental rural, avanço ou retrocesso?. Revista Eletrônica Direito e Política, Programa de Pós-Graduação Stricto Sensu em Ciência Jurídica da UNIVALI, Itajaí, v.10, n.1, edição especial de 2015. Disponível em: www.univali.br/direitoepolitica - ISSN 1980-7791.

O antigo Código Florestal, Lei no 4.771/1965, previa em seu $\S 80$, art. 16, que a área de Reserva Legal deveria ser averbada à margem da inscrição da matrícula do imóvel, no registro de imóveis competente.

Para lograr êxito na averbação, diversos documentos deveriam ser apresentados pelo interessado, dentre eles destacam-se: a prévia aprovação do órgão ambiental competente (termo de reserva legal aprovado pela FATMA), planta assinada pelo engenheiro e proprietários, com anotação de responsabilidade técnica - ART.

Ocorre que o novo Código Florestal, Lei no 12.651 de 2012, revogou referido dispositivo e estabeleceu como necessário, a partir de então, no parágrafo 4o. do seu artigo 18, apenas o registro da Reserva Legal no Cadastro Ambiental Rural $\mathrm{CAR}^{22}$.

\section{CADASTRO AMBIENTAL RURAL}

O Cadastro Ambiental Rural (CAR) é um instrumento que visa auxiliar no processo de regularização ambiental de propriedades e posses rurais. O CAR revela-se uma base de dados estratégica para o controle, o monitoramento e o combate ao desmatamento das florestas e demais formas de vegetação nativa do Brasil e mostra-se instrumento para planejamento ambiental e econômico dos imóveis rurais.

O CAR foi criado, no âmbito nacional, pela Lei no 12.651, de 25 de maio de 2012 e sua regulamentação se deu por meio do Decreto $n^{\circ} 7.830$, de 17 de outubro de 2012. Referido decreto criou o Sistema de Cadastro Ambiental Rural - SICAR, que tem como finalidade integrar o CAR de todas as Unidades da Federação.

Trata-se de registro público eletrônico no qual, obrigatoriamente, todos os

22 Art. 18 (...0 $\S 4^{0}$ O registro da Reserva Legal no CAR desobriga a averbação no Cartório de Registro de Imóveis, sendo que, no período entre a data da publicação desta Lei e o registro no CAR, o proprietário ou possuidor rural que desejar fazer a averbação terá direito à gratuidade deste ato.(Redação dada pela Lei no 12.727, de 2012). Disponível em: http://www.planalto.gov.br/ccivil_03/_ato2011-2014/2012/lei//12651.htm, acesso em 16/12/2014. 
D'ÁVILA, Gilmara Vanderlinde Medeiros. Averbação da reserva legal x Cadastro ambiental rural, avanço ou retrocesso?. Revista Eletrônica Direito e Política, Programa de Pós-Graduação Stricto Sensu em Ciência Jurídica da UNIVALI, Itajaí, v.10, n.1, edição especial de 2015. Disponível em: www.univali.br/direitoepolitica - ISSN 1980-7791.

imóveis rurais devem ser cadastrados.

O Ministério do Meio Ambiente editou a Instrução Normativa n. 02, de 05 de maio de 2014, que considerou o CAR implantado no âmbito nacional e inaugurou o prazo legal de um (01) ano, para adesão dos possuidores rurais e proprietários ao cadastro.

Consoante expõe o Ministério do Meio Ambiente, o CAR consiste no levantamento de informações georreferenciadas do imóvel, com delimitação das Áreas de Proteção Permanente (APP), Reserva Legal (RL), remanescentes de vegetação nativa, área rural consolidada, áreas de interesse social e de utilidade pública, com o objetivo de traçar um mapa digital a partir do qual são calculados os valores das áreas para diagnóstico ambiental. ${ }^{23}$

Como benefícios do CAR destacam-se: o de possibilitar o planejamento ambiental e econômico do uso e ocupação do imóvel rural, a inscrição no CAR, acompanhada de compromisso de regularização ambiental quando for o caso, é pré-requisito para acesso à emissão das Cotas de Reserva Ambiental e aos benefícios previstos nos Programas de Regularização Ambiental - PRA e de Apoio e Incentivo à Preservação e Recuperação do Meio Ambiente, ambos definidos pela Lei $12.651 / 12^{24}$. Dentre os benefícios desses programas citam-se:

\begin{abstract}
Possibilidade de regularização das APP e/ou Reserva Legal vegetação natural suprimida ou alterada até 22/07/2008 no imóvel rural, sem autuação por infração administrativa ou crime ambiental; Suspensão de sanções em função de infrações administrativas por supressão irregular de vegetação em áreas de APP, Reserva Legal e de uso restrito, cometidas até $22 / 07 / 2008$. Obtenção de crédito agrícola, em todas as suas modalidades, com taxas de juros menores, bem como limites e prazos maiores que o praticado no mercado; Contratação do seguro agrícola em condições melhores que as praticadas no mercado; Dedução das Áreas de Preservação Permanente, de Reserva Legal e de uso restrito base de cálculo do Imposto sobre a Propriedade Territorial Rural-ITR, gerando créditos tributários.
\end{abstract}

${ }^{23}$ Disponível em: http://www.mma.gov.br/desenvolvimento-rural/cadastro-ambiental-rural, acesso em 25/09/2014.

24 Disponível em: http://www.car.gov.br/\#/sobre, acesso em 25/09/2014. 
D'ÁVILA, Gilmara Vanderlinde Medeiros. Averbação da reserva legal x Cadastro ambiental rural, avanço ou retrocesso?. Revista Eletrônica Direito e Política, Programa de Pós-Graduação Stricto Sensu em Ciência Jurídica da UNIVALI, Itajaí, v.10, n.1, edição especial de 2015. Disponível em: www.univali.br/direitoepolitica - ISSN 1980-7791.

Referidos programas ainda prevêem linhas de financiamento atender iniciativas de preservação voluntária de vegetação nativa, proteção de espécies da flora nativa ameaçadas de extinção, manejo florestal e agroflorestal sustentável realizados na propriedade ou posse rural, ou recuperação de áreas degradadas; e Isenção de impostos, isenções deferidas aos principais insumos e equipamentos ${ }^{25}$, tais como:

fio de arame, postes de madeira tratada, bombas d'água, trado de perfuração do solo, dentre outros utilizados para os processos de recuperação e manutenção das Áreas de Preservação Permanente, de Reserva Legal e de uso restrito. ${ }^{26}$

Entretanto, também diversas críticas são tecidas ao referido sistema, principalmente no que diz respeito ao processo de estabelecimento nacional do sistema, que apresenta fragilidades.

"O sistema nacional que o Ministério do Meio Ambiente (MMA) está desenvolvendo apresenta fragilidades, o que poderá comprometer a qualidade do CAR. Esse sistema será adotado pelos estados que não tiverem sistemas próprios de cadastramento". 27

"Com o objetivo de simplificar o processo, esse sistema retira a obrigatoriedade de um técnico para a realização do cadastro e, assim, permite que o próprio produtor rural faça a sua planta do imóvel com a delimitação do perímetro e das respectivas áreas de conservação, diretamente sobre a imagem de satélite". ${ }^{28}$

Critica Camargo, argumentando que,

Embora possa parecer que essa estratégia facilitará, a princípio, a inscrição dos produtores, ela dificultará a

\footnotetext{
25 Disponível em: http://www.car.gov.br/\#/sobre, acesso em 25/09/2014.

${ }^{26}$ Disponível em: http://www.car.gov.br/\#/sobre, acesso em 25/09/2014.

27 CAMARGO, Flavia. Os rumos do cadastro ambiental precisam mudar. Disponível em: http://www.socioambiental.org/pt-br/blog/blog-do-ppds/os-rumos-do-cadastro-ambiental-ruralcar-precisam-mudar, acesso em 25/09/2014.

28 CAMARGO, Flavia. Os rumos do cadastro ambiental precisam mudar. Disponível em: http://www.socioambiental.org/pt-br/blog/blog-do-ppds/os-rumos-do-cadastro-ambiental-ruralcar-precisam-mudar, acesso em 25/09/2014.
} 
D'ÁVILA, Gilmara Vanderlinde Medeiros. Averbação da reserva legal x Cadastro ambiental rural, avanço ou retrocesso?. Revista Eletrônica Direito e Política, Programa de Pós-Graduação Stricto Sensu em Ciência Jurídica da UNIVALI, Itajaí, v.10, n.1, edição especial de 2015. Disponível em: www.univali.br/direitoepolitica - ISSN 1980-7791.

validação do CAR. Elaborar plantas georreferenciadas (art. 50 do Decreto 7.830/12) não é uma tarefa trivial, principalmente se considerarmos a necessidade de uma precisão mínima para identificar as Áreas de Preservação Permanente (APP) que, de acordo com a nova legislação, poderão ter dimensões a partir de 5 metros. Além disso, identificar as APPs em função da declividade poderá ser uma tarefa ainda mais complexa. Também não é simples compreender a legislação florestal, a qual possui uma série de termos técnicos e situações particularizadas conforme a data do desmatamento e o tamanho da propriedade. ${ }^{29}$

Percebe-se, assim, que o sistema possibilita a inserção de dados errados e imprecisos, pois dispensa a capacitação técnica, o que era imprescindível no regime anterior, pois a análise e a aprovação pelo órgão ambiental era prévia.

Como os órgãos ambientais terão o trabalho de validar todas estas informações, percebe-se, de antemão, que isso não será tarefa fácil e rápida, diante da possibilidade de inúmeros erros na alimentação dos dados e até mesmo má-fé por parte de alguns, o que, certamente, seria reduzido, caso as informações somente pudessem ser prestadas por pessoas legalmente habilitadas e sob responsabilidade.

O pior é que de acordo com o artigo $2^{\circ}$. do Decreto 7.830/12, a demora na manifestação do órgão ensejará a validade temporária dos cadastros.

"Desta forma, estes cadastros, que não foram feitos com a acurácia e a qualificação técnica necessárias, ficarão valendo para todos os fins previstos em lei, até que os órgãos ambientais se manifestem". ${ }^{30}$

Neste sentido, registra Camargo que,

Isso poderá prejudicar, inclusive, as políticas de incentivo econômico à conservação que estão sendo formuladas e que precisam de um cadastro de qualidade para funcionar. É

29 CAMARGO, Flavia. Os rumos do cadastro ambiental precisam mudar. Disponível em: http://www.socioambiental.org/pt-br/blog/blog-do-ppds/os-rumos-do-cadastro-ambiental-ruralcar-precisam-mudar, acesso em 25/09/2014.

30 CAMARGO, Flavia. Os rumos do cadastro ambiental precisam mudar. Disponível em: http://www.socioambiental.org/pt-br/blog/blog-do-ppds/os-rumos-do-cadastro-ambiental-ruralcar-precisam-mudar, acesso em 25/09/2014. 
D'ÁVILA, Gilmara Vanderlinde Medeiros. Averbação da reserva legal x Cadastro ambiental rural, avanço ou retrocesso?. Revista Eletrônica Direito e Política, Programa de Pós-Graduação Stricto Sensu em Ciência Jurídica da UNIVALI, Itajaí, v.10, n.1, edição especial de 2015. Disponível em: www.univali.br/direitoepolitica - ISSN 1980-7791.

preciso rever essa estratégia de CAR baseada no "desenho" feito pelos produtores, sem um responsável técnico. O CAR é para ser um instrumento de planejamento territorial e de monitoramento da cobertura florestal dos imóveis rurais e para isso precisa atender a determinadas especificações técnicas. Facilitar a inscrição no CAR, prescindindo da qualidade, é criar um instrumento sem eficácia, que não justifica todo o investimento público já realizado. ${ }^{31}$

Ainda que aos órgãos ambientais competentes seja facultado realizar vistorias no imóvel e solicitar esclarecimentos cabíveis, a natureza declaratória do CAR gera certa insegurança acerca da veracidade das informações prestadas (especialmente se levarmos em conta nossas proporções continentais e o déficit no quesito fiscalização - ações de comando e controle, infelizmente, ainda são o método mais eficaz de assegurar eficácia das normas). ${ }^{32}$

Segundo Camargo, uma das justificativas apresentadas pelo MMA para que o CAR tenha um processo o mais simplificado possível é a de que os prazos da lei são exíguos. Todos os produtores deverão estar inscritos no CAR até dois anos após a implantação do sistema ${ }^{33}$. Prossegue Camargo afirmando que:

Como a lei não determinou um prazo para que os cadastros sejam validados, o MMA não está atento ao fato de que um sistema como esse poderá até possibilitar o cadastramento no prazo de dois anos, mas implicará numa morosidade significativa no processo de validação, tendo em vista o número de imprecisões e erros que o sistema induzirá.

Outro argumento utilizado para se preterir do apoio técnico é que poderá não haver profissionais suficientes para realizar o CAR no tempo hábil determinado pela lei. Mesmo que isso seja uma possibilidade, este também não é um argumento válido. Que valor teria um CAR com uma série de inconsistências e pendências? De que adianta acelerar o processo de cadastramento dos produtores para cumprir os

31 CAMARGO, Flavia. Os rumos do cadastro ambiental precisam mudar. Disponível em: http://www.socioambiental.org/pt-br/blog/blog-do-ppds/os-rumos-do-cadastro-ambiental-ruralcar-precisam-mudar, acesso em 25/09/2014.

32 VILARINHO, Renata. ÁREAS DE PRESERVAÇÃo. Cadastro Ambiental Rural traz a tão esperada simplificação. Disponível em: http://www.conjur.com.br/2014-mai-14/renata-vilarinho-cadastroambiental-rural-traz-tao-esperada-simplificacao, acesso em 25/09/2014.

33 CAMARGO, Flavia. Os rumos do cadastro ambiental precisam mudar. Disponível em: http://www.socioambiental.org/pt-br/blog/blog-do-ppds/os-rumos-do-cadastro-ambiental-ruralcar-precisam-mudar, acesso em 25/09/2014. 
D'ÁVILA, Gilmara Vanderlinde Medeiros. Averbação da reserva legal x Cadastro ambiental rural, avanço ou retrocesso?. Revista Eletrônica Direito e Política, Programa de Pós-Graduação Stricto Sensu em Ciência Jurídica da UNIVALI, Itajaí, v.10, n.1, edição especial de 2015. Disponível em: www.univali.br/direitoepolitica - ISSN 1980-7791.

prazos se os órgãos ambientais (que também têm poucos técnicos) terão maior dificuldade em validar os cadastros.

Camargo conclui que, permitir um sistema frágil de cadastramento para que metas quantitativas sejam atingidas não apenas impossibilita resolver o problema como cria outros. ${ }^{34}$ Levando isso em conta salienta a necessidade de os cadastros no CAR tenham o devido acompanhamento técnico. ${ }^{35}$

Conforme dispõe a Lei n. 12.651/12, que criou o CAR, a averbação da reserva legal junto a matrícula imobiliária, no Registro de Imóveis, tornou-se facultativa, quando a mesma já estiver registrada no Cadastro Ambiental Rural (CAR).

Ocorre que não foi implementado, em vários Estados, o Cadastro Ambiental Rural, de modo que, nesses Estados, a obrigação de averbação na matrícula do imóvel se mantém. O novo Código Florestal desobriga a averbação no Cartório de Registro de Imóveis apenas se for registrada a Reserva Legal no CAR. Logo, ausente no respectivo Estado, devem os interessados cumprir o encargo de averbar a reserva. Sobre $o$ assunto colhem-se as seguintes decisões ${ }^{36}$ :

RETIFICAÇÃO DE REGISTRO DE IMÓVEIS. DECISÃO QUE DETERMINOU FOSSE AVERBADA A RESERVA LEGAL NAS MATRÍCULAS DOS BENS OBJETOS DA DEMANDA. INSURGÊNCIA. ALEGAÇÃO QUE O NOVO CÓDIGO FLORESTAL ABOLIU A OBRIGAÇÃO, QUE ESTAVA PREVISTA APENAS NO ANTIGO DIPLOMA. INTERPRETAÇÃO EQUIVOCADA. REGRAMENTO VIGENTE QUE DESOBRIGA A AVERBAÇÃO SE EFETUADO O REGISTRO DA RESERVA LEGAL NO CADASTRO AMBIENTAL RURAL (CAR), SISTEMA AINDA NÃO IMPLEMENTADO NO ESTADO DE SANTA CATARINA. NECESSÁRIA, PORTANTO, A AVERBAÇÃO NO CARTÓRIO DO REGISTRO DE IMÓVEIS. (...) (TJSC, Agravo de Instrumento n. 2013.060735-4, de Ibirama, rel. Des. Gilberto Gomes de

34 CAMARGO, Flavia. Os rumos do cadastro ambiental precisam mudar. Disponível em: http://www.socioambiental.org/pt-br/blog/blog-do-ppds/os-rumos-do-cadastro-ambiental-ruralcar-precisam-mudar, acesso em 25/09/2014.

35 CAMARGO, Flavia. Os rumos do cadastro ambiental precisam mudar. Disponível em: http://www.socioambiental.org/pt-br/blog/blog-do-ppds/os-rumos-do-cadastro-ambiental-ruralcar-precisam-mudar, acesso em 25/09/2014

36 No mesmo sentido decisão do CNJ, no Procedimento de Controle Administrativo n. 000211822.2013.2.00. 0000, rel. Cons. Neves Amorim, j. 19.4.2013. Disponível em: http://www.portaldori.com.br/2014/03/12/procedimento-de-controle-administrativo-0002118-222013-2-00-0000/, acesso em 29/09/2014. 
D'ÁVILA, Gilmara Vanderlinde Medeiros. Averbação da reserva legal x Cadastro ambiental rural, avanço ou retrocesso?. Revista Eletrônica Direito e Política, Programa de Pós-Graduação Stricto Sensu em Ciência Jurídica da UNIVALI, Itajaí, v.10, n.1, edição especial de 2015. Disponível em: www.univali.br/direitoepolitica - ISSN 1980-7791.

Oliveira, j. 21-08-2014)..$^{37}$

Mandado de segurança. (...) Averbação de área de reserva legal na matrícula de imóvel determinada por Ofício-Circular da Corregedoria-Geral de Justiça, abolida pelo novo Código Florestal (Lei n. 12.651/12), mas condicionada ao registro em Cadastro Ambiental Rural (Art. 18, caput e $\S 4^{\circ}$ ). Não implementação do CAR, ainda, em Santa Catarina. Subsistência, por isso, da obrigação anterior. Precedente desta Corte. Ordem denegada. (...) Subsiste, portanto, a obrigação constante da Lei no 6.015, de 1973-. (CNJ, Procedimento de Controle Administrativo n. 000211822.2013.2.00. 0000, rel. Cons. Neves Amorim, j. 19.4.2013). (TJSC, Mandado de Segurança n. 2013.0484141, da Capital, rel. Des. Pedro Manoel Abreu, j. 14-052014). ${ }^{38}$

\section{PRINCÍPIOS NORTEADORES DO DIREITO AMBIENTAL - PRINCÍPIO DA VEDAÇÃO AO RETROCESSO E PRINCÍPIO DA INFORMAÇÃO.}

Consoante Canotilho, entende-se por proibição do retrocesso a ideia de que, porquanto assegurados no plano infraconstitucional, os direitos fundamentais adquirem o status de direitos subjetivos, de maneira que o legislador não pode mais reduzi-los ou suprimi-los. ${ }^{39}$

Para Aragão, o princípio da proibição do retrocesso ecológico é uma versão "diacronicamente orientada" do princípio do nível elevado de proteção ecológica aplicável tanto no plano internacional, como nas ordens jurídicas estaduais ${ }^{40}$. Prossegue referida autora afirmando que:

No plano interno, especificamente, trata-se de uma espécie de cláusula "rebus sic standibus", ou seja, implica assumir que, salvo alteração drástica das circunstâncias de fato - por

\footnotetext{
37 Disponível em: http://busca.tjsc.jus.br/jurisprudencia/html.do?q=\&only_ementa=\&frase $=\& \mathrm{id}=$ AAAbmQAACAAI1XNAAY\&categoria=acordao, acesso em 16/12/2014.

38 Disponível em: http://busca.tjsc.jus.br/jurisprudencia/html.do?q=\&only_ementa=\&frase=\&id =AAAbmQAACAAGjB6AAF\&categoria=acordao, acesso em 16/12/2014.

39 CANOTILHO, José Joaquim Gomes. Direito Constitucional e Teoria da Constituição. 3 ed. Coimbra: Almedina, 1999, p. 474.
}

40 ARAGÃO, Alexandra. Direito constitucional do ambiente da União Européia. In: CANOTILHO, José Joaquim Gomes; LEITE, José Rubens Morato (orgs.). Direito Constitucional Ambiental Brasileiro. São Paulo: Saraiva, 2007, 433 p, pp. 11-55, p. 36-37. 
D'ÁVILA, Gilmara Vanderlinde Medeiros. Averbação da reserva legal x Cadastro ambiental rural, avanço ou retrocesso?. Revista Eletrônica Direito e Política, Programa de Pós-Graduação Stricto Sensu em Ciência Jurídica da UNIVALI, Itajaí, v.10, n.1, edição especial de 2015. Disponível em: www.univali.br/direitoepolitica - ISSN 1980-7791.

exemplo, a confirmação científica de que a lei vigente era inadequada, ou afastamento de um suposto perigo - é inadmissível "o recuo para níveis de protecção aos inferiores anteriormente consagrados". ${ }^{41}$

Consoante Fensterseifer:

A proibição de retrocesso ambiental, da mesma forma como ocorre com a proibição de retrocesso social, está relacionada ao princípio da segurança jurídica, da proteção da confiança ou mesmo de previsibilidade no enquadramento normativo das relações jurídicas (as garantias constitucionais do direito adquirido, do ato jurídico perfeito e da coisa julgada, bem como os limites das matérias à reforma constitucional são expressão do princípio constitucional da segurança jurídica), o que se apresenta como um traço característico da conformação do Estado de Direito. De outra forma, o que se está a determinar com a proibição de retrocesso é a subordinação do legislador infraconstitucional ao comando normativo constitucional, em respeito ao princípio da supremacia da Constituição. ${ }^{42}$

Registra Sarlet que,

a proibição de retrocesso constitui-se de um princípio constitucional implícito, tendo como fundamento constitucional, entre outros, o princípio do Estado (democrático e social) de Direito, o princípio da dignidade da pessoa humana, o principio da máxima eficacia e efetividade das normas definidoras de direitos fundamentais, as garantias expressamente previstas (ato jurídico perfeito, direito adquirido e coisa julgada), o princípio da segurança jurídica e o princípio da proteção de confiança. ${ }^{43}$

"O princípio da proibição de retrocesso ambiental (ou ecológico) seria concebido no sentido de que a tutela normativa ambiental deve operar de modo progressivo no âmbito das relações jurídicas". ${ }^{44}$ Portanto, o princípio é concebido com a

41 ARAGÃO, Alexandra. Direito constitucional do ambiente da União Européia. In: CANOTILHO, José Joaquim Gomes; LEITE, José Rubens Morato (orgs.). Direito Constitucional Ambiental Brasileiro. São Paulo: Saraiva, 2007, 433 p, pp. 11-55, p. 36-37.

42 FENSTERSEIFER, Tiago. Direitos fundamentais e proteção do ambiente: a dimensão ecológica da dignidade humana no marco jurídico constitucional do estado socioambiental de direito. 2008, p. 258.

${ }^{43}$ SARLET, Ingo Wolfgang. A eficacia dos direitos fundamentais. 5a. ed. Porto Alegre: Livraria do Advogado, 2005, p. 427-428.

44 FENSTERSEIFER, Tiago. Direitos fundamentais e proteção do ambiente: a dimensão ecológica da dignidade humana no marco jurídico constitucional do estado socioambiental de 
D'ÁVILA, Gilmara Vanderlinde Medeiros. Averbação da reserva legal x Cadastro ambiental rural, avanço ou retrocesso?. Revista Eletrônica Direito e Política, Programa de Pós-Graduação Stricto Sensu em Ciência Jurídica da UNIVALI, Itajaí, v.10, n.1, edição especial de 2015. Disponível em: www.univali.br/direitoepolitica - ISSN 1980-7791.

finalidade de:

ampliar a qualidade de vida existente hoje e atender a padrões cada vez mais rigorosos de tutela da dignidade humana, não retrocedente jamais a um nível de proteção inferior àquela verificado hoje $\mathrm{e}^{45}$.

Fensterseifer destaca a necessidade de blindarmos as leis ambientais do retrocesso, afirmando:

Assim, no caso especialmente da legislação ambiental que busca dar operatividade ao dever constitucional de proteção do ambiente, há que assegurar a sua blindagem contra retrocessos que a tornem menos rigorosa ou flexível, admitindo práticas poluidoras hoje proibidas, assim como buscar sempre um nível mais rigoroso de proteção. ${ }^{46}$

A Lei $6.938 / 1981$, em seus artigos $6^{\circ}, \S 3^{\circ} 1$, e $10^{\circ}$, § 10. já previa o Princípio da Informação Ambiental.

A Lei $10.650 / 2003$, por sua vez, dispõe sobre o acesso público aos dados e às informações ambientais existentes em órgãos e entidades integrantes do Sistema Nacional do Meio Ambiente - SISNAMA. Referida lei garante o acesso público a documentos e a processos administrativos, que tratem de matéria ambiental.

Por fim, o princípio da informação se faz presente no texto constitucional vigente, especificamente no inciso VI do $\S 10$ do artigo $225^{47}$.

Consoante garante o princípio da informação, o indivíduo tem direito a ter acesso às informações relativas ao meio ambiente, que as autoridades públicas

direito. 2008, p. 261.

45 FENSTERSEIFER, Tiago. Direitos fundamentais e proteção do ambiente: a dimensão ecológica da dignidade humana no marco jurídico constitucional do estado socioambiental de direito. 2008, p. 261.

46 SARLET, Ingo Wolfgang e FENSTERSEIFER, Tiago. Direito Constitucional Ambiental: constituição, direitos fundamentais e proteção do ambiente. 3a. ed. Rev. Atual. E ampli.. São Paulo: Revista dos Tribunais, 2013, p. 299.

47 Art. 225. Todos têm direito ao meio ambiente ecologicamente equilibrado, bem de uso comum do povo e essencial à sadia qualidade de vida, impondo-se ao Poder Público e à coletividade o dever de defendê-lo e preservá- lo para as presentes e futuras gerações. $\S 10$ - Para assegurar a efetividade desse direito, incumbe ao Poder Público:(...) VI - promover a educação ambiental em todos os níveis de ensino e a conscientização pública para a preservação do meio ambiente; 
D'ÁVILA, Gilmara Vanderlinde Medeiros. Averbação da reserva legal x Cadastro ambiental rural, avanço ou retrocesso?. Revista Eletrônica Direito e Política, Programa de Pós-Graduação Stricto Sensu em Ciência Jurídica da UNIVALI, Itajaí, v.10, n.1, edição especial de 2015. Disponível em: www.univali.br/direitoepolitica - ISSN 1980-7791.

dispõem.

A informação serve para o processo de educação de cada pessoa e da comunidade. Mas a informação visa, também, a dar chance à pessoa informada de tomar posição ou pronunciar-se sobre a matéria informada. ${ }^{48}$

A Declaração das Nações Unidas sobre Meio Ambiente e Desenvolvimento, ocorrida no Rio de Janeiro, no ano de 1992, em seu princípio 10, já previa que:

[...] a melhor maneira de tratar questões ambientais é assegurar a participação, no nível apropriado, de todos os cidadãos interessados. No nível nacional, cada indivíduo terá acesso adequado às informações relativas ao meio ambiente de que disponham as autoridades públicas, inclusive informações sobre materiais e atividades perigosas em suas comunidades, bem como a oportunidade de participar dos processos decisórios. Os Estados irão facilitar e estimular a conscientização e a participação popular, colocando as informações à disposição de todos $[\ldots]^{49}$

Consoante mencionam AMADEI, MIRRA e NOVA, a orientação estabelecida, de procurar assegurar ampla informação e publicidade a respeito do estado do meio ambiente não só atende ao interesse público nessa matéria ambiental, que impõe amplitude de informação. 50

Concentrar no fólio real a notícia de contaminação, oficialmente declarada, do imóvel respectivo, agrega, sem dúvida, segurança jurídica formal, estática e dinâmica, própria do registro predial. 51

Ocorre que, comparando-se as disposições legais previstas no antigo Código Florestal, Lei 4.771/1965, com as vigentes no novo Código, Lei 12.651/2012, resta flagrante o abrandamento do rigor dispensado aos institutos da reserva

\footnotetext{
${ }^{48}$ MACHADO, Paulo Affonso Leme. Estudos de direito ambiental. São Paulo: Malheiros, 1994, p. 86.

49 ONU. Conferencia das Nações Unidas sobre Meio Ambiente e Desenvolvimento, tendo se reunido no Rio de Janeiro, de 3 a 14 de junho de 1992. Disponível em: www.onu.org.br/rio20/img/2012/01/rio92.pdf, acesso em 23/11/2013.

50 NOVA, A. L. V. e AMADEI, V de A. IN: DIP, Ricardo e JACOMINO, Sérgio. (Org.) Propriedade e direitos reais limitados. 2012, v. 5, p. 1077.

${ }^{51}$ NOVA, A. L. V. e AMADEI, V de A. IN: DIP, Ricardo e JACOMINO, Sérgio. (Org.) Propriedade e direitos reais limitados. 2012, v. 5, p. 1077.
} 
D'ÁVILA, Gilmara Vanderlinde Medeiros. Averbação da reserva legal x Cadastro ambiental rural, avanço ou retrocesso?. Revista Eletrônica Direito e Política, Programa de Pós-Graduação Stricto Sensu em Ciência Jurídica da UNIVALI, Itajaí, v.10, n.1, edição especial de 2015. Disponível em: www.univali.br/direitoepolitica - ISSN 1980-7791.

legal e da área de preservação permanente, com a flexibilização das normas e diminuição da publicidade, fruto da pressão política, visando conferir maior aproveitamento econômico às propriedades, em detrimento da proteção ambiental e em franca violação ao princípio da vedação ao retrocesso ambiental e ao princípio da informação.

\section{O PAPEL DO REGISTRO DE IMÓVEIS}

O Registro de Imóveis é serviço público, de organização técnico-administrativa, destinado a garantir a publicidade, autenticidade, segurança e eficácia dos atos jurídicos, consoante preceitua o artigo 10. da Lei 8.935/1994.

A função de registrar imóveis é delegada a particulares aprovados em concurso público, de provas e títulos, conforme artigo 236 da CF/1988. Referidos particulares além de terem deveres legais a zelar ${ }^{52}$, são constantemente fiscalizados pelos Órgãos do Poder Judiciário - Corregedorias locais e até mesmo pelo Conselho Nacional de Justiça - e pela própria população.

Esclarece Cavedon que, a publicidade registral se destina ao cumprimento de tríplice função:

a) transmite ao conhecimento de terceiros interessados ou não interessados a informação do direito correspondente ao conteúdo do registro; b) sacrifica parcialmente a privacidade e a intimidade das pessoas, informando sobre bens e direitos seus ou que lhes sejam referentes, a benefício das garantias advindas do registro; c) serve para fins estatísticos, de interesse nacional ou de fiscalização pública. ${ }^{53}$

52 Lei 8.935/94, artigo 30. São deveres dos notários e dos oficiais de registro: I - manter em ordem os livros, papéis e documentos de sua serventia, guardando-os em locais seguros; II atender as partes com eficiência, urbanidade e presteza; III - atender prioritariamente as requisições de papéis, documentos, informações ou providências que Ihes forem solicitadas pelas autoridades judiciárias ou administrativas para a defesa das pessoas jurídicas de direito público em juízo; (...) X - observar os prazos legais fixados para a prática dos atos do seu ofício; (...) XII facilitar, por todos os meios, o acesso à documentação existente às pessoas legalmente habilitadas(...). BRASIL. Presidência da República. Lei no 8.935, de 18 de novembro de 1994. Regulamenta o art. 236 da Constituição Federal, dispondo sobre serviços notariais e de registro. Publicada no DOU de 21.11.1994. Disponível em: http://www.planalto.gov.br/ccivil_03/leis/18935.htm, acesso em 29/09/2014.

${ }^{53}$ CAVEDON, Fernanda de Salles. Função Social e Ambiental da Propriedade. Florianópolis: 
D'ÁVILA, Gilmara Vanderlinde Medeiros. Averbação da reserva legal x Cadastro ambiental rural, avanço ou retrocesso?. Revista Eletrônica Direito e Política, Programa de Pós-Graduação Stricto Sensu em Ciência Jurídica da UNIVALI, Itajaí, v.10, n.1, edição especial de 2015. Disponível em: www.univali.br/direitoepolitica - ISSN 1980-7791.

Portanto, "a publicidade é a alma dos registros públicos. É a oportunidade que o legislador quer dar ao povo de conhecer tudo que lhe interessa a respeito de determinados atos. Deixar a par de todo o movimento de pessoas e bens". ${ }^{54}$

A publicidade dos atos registrais é garantida pela Lei 6.015/1973 e também Constituição Federal, no inciso XXXIII do artigo 50.

Portanto, revela-se de suma importância que todas as informações sobre o imóvel estejam reunidas na matrícula do imóvel, em consonância com o princípio da publicidade e o princípio da concentração, ${ }^{55}$ sendo preocupante o fato de que, com o novo Código Florestal, seja apenas facultativa a averbação da reserva legal - com sua delimitação e correta localização -, na matrícula do imóvel.

Não se pode esquecer que "a educação ambiental, que inclui em certa medida o acesso às informações ambientais, compõe-se de condição para a cidadania no Estado Socioambiental de Direito, porquanto só a partir de tal pressuposto o exercício democrático será viabilizado de forma qualificada e participativa." ${ }^{56}$

Assim, despiu-se a população, bem como, o possível adquirente, de uma importante ferramenta de informação pois, o Registrador possuía um prazo legal de apenas cinco (05) dias para prestar as informações solicitadas, fornecendo a competente certidão de matrícula do imóvel, na qual a reserva legal apareceria delimitada, caso estivesse averbada, inclusive cópia dos mapas de sua especificação; sendo que o interessado não necessitaria comprovar o motivo ou o interesse do pedido, conforme preceituam os artigos 16 a 18 da Lei $6.015 / 1973^{57}$.

Visualbooks, 2003, p. 75.

${ }^{54}$ BALBINO FILHO. Nicolau. Registro de Imóveis. São Paulo: Saraiva, 9a. Edição, 1999, p. 09.

55 No registro de imóveis serão feitas, além da matrícula, todas as averbações e quaisquer ocorrências que alterem o registro dos bens ali registrados (art. 167, II, da n. Lei 6.015/73).

56 FENSTERSEIFER, Tiago. Direitos fundamentais e proteção do ambiente: a dimensão ecológica da dignidade humana no marco jurídico constitucional do estado socioambiental de direito. 2008, p. 88.

57 BRASIL. Presidência da República. Lei no 6.015, de 31 de dezembro de 1973. Dispõe sobre os registros públicos, e dá outras providências. Publicada no DOU de 31.12.1973. Disponível em: http://www.planalto.gov.br/ccivil_03/leis/l6015.htm , acesso em 19/11/2013. Art. 16. Os oficiais e os encarregados das repartições em que se façam os registros são obrigados: $1^{\circ}$ a lavrar certidão 
D'ÁVILA, Gilmara Vanderlinde Medeiros. Averbação da reserva legal x Cadastro ambiental rural, avanço ou retrocesso?. Revista Eletrônica Direito e Política, Programa de Pós-Graduação Stricto Sensu em Ciência Jurídica da UNIVALI, Itajaí, v.10, n.1, edição especial de 2015. Disponível em: www.univali.br/direitoepolitica - ISSN 1980-7791.

Com a facultatividade, certamente, nada mais de reservas legais se averbarão nas matrículas dos imóveis e os interessados deverão dirigir seus pedidos de informações sobre reservas legais unicamente ao Órgão Público competente para, quem sabe um dia, receberem a informação de que necessitam.

Quanto a obrigatoriedade de averbação da inscrição no CAR na matrícula do imóvel, apesar de não haver dispositivo expresso no novo Código Florestal, entendemos pela necessidade, tendo em vista a função socioambiental dos Registros de Imóveis, de guardiões da propriedade imobiliária e do direito de propriedade; da mesma forma é o entendimento externado pelo Colégio Registral Imobiliário de Santa Catarina ${ }^{58}$, fundamentando-se nos princípios da concentração e da publicidade (artigo 167, inciso II, item 5 e artigo 246, ambos da Lei $6.015 / 73)^{59}$.

Além desses dispositivos e princípios, fundamentamos a obrigatoriedade da nova averbação também no princípio da vedação ao retrocesso ambiental, pois é inconcebível que nada mais de informações sobre reserva legal seja mencionado na matrícula do imóvel.

Ainda, a fundamentar a obrigatoriedade de averbação da inscrição no CAR na matrícula do imóvel, cita-se o fato de que não houve revogação expressa da alínea 22 do inciso II do artigo 167 da Lei n.0 6.015, de 31 de dezembro de $1973^{60}$, bem como, o disposto no artigo 246 da mesma lei - que prevê que serão averbados na matrícula as subrogações e outras ocorrências que, por qualquer

do que Ihes for requerido; $2^{\circ}$ a fornecer às partes as informações solicitadas. Art. 17. Qualquer pessoa pode requerer certidão do registro sem informar ao oficial ou ao funcionário o motivo ou interesse do pedido. Art. 18. Ressalvado o disposto nos arts. 45, 57, § 70, e 95, parágrafo único, a certidão será lavrada independentemente de despacho judicial, devendo mencionar o livro de registro ou o documento arquivado no cartório. (Redação dada pela Lei no 9.807, de 1999). Art. 19. A certidão será lavrada em inteiro teor, em resumo, ou em relatório conforme quesitos e devidamente autenticada pelo oficial ou por seus substitutos legais, não podendo ser retardada por mais de cinco (5) dias.

58 Externada por meio do Ofício n. 15/2014, datado de 12/09/2014, endereçado ao ViceCorregedor Geral de Justiça do c. TJSC.

${ }^{59}$ No mesmo sentido, o c. TJSP editou o PROVIMENTO CG N.0 36/2013, Publicado em 08/11/2013, que prevê a obrigatóriedade da averbação na matrícula do Imóvel do número de inscrição no CAR.

60 "Art. 167 - No Registro de Imóveis, além da matrícula, serão feitos. (...) II - a averbação: (...) 22. da reserva legal; (...) Art. 169 - Todos os atos enumerados no art. 167 são obrigatórios e efetuar-se-ão no Cartório da situação do imóvel". 
D'ÁVILA, Gilmara Vanderlinde Medeiros. Averbação da reserva legal x Cadastro ambiental rural, avanço ou retrocesso?. Revista Eletrônica Direito e Política, Programa de Pós-Graduação Stricto Sensu em Ciência Jurídica da UNIVALI, Itajaí, v.10, n.1, edição especial de 2015. Disponível em: www.univali.br/direitoepolitica - ISSN 1980-7791.

modo, alterem o registro -, tendo em vista que é pacífico nos Tribunais o fato de que a reserva legal é um ônus incidente sobre o imóvel, e como tal, deve estar devidamente mencionada na matrícula.

"A publicidade de informações ambientais agrega segurança jurídica aos registros imobiliários e amplia a proteção dos espaços legal e especialmente protegidos, o controle e transparência dos negócios imobiliários, funções das serventias prediais." 61

Não se pode esquecer, ainda, "as diferenças entre Cadastro e Registro, a importância do fluxo de informações entre um e outro e da integração do sistema registral com os demais instrumentos de tutela ambiental". ${ }^{62}$

Como forma de beneficiar os que efetivamente e tempestivamente cumpriram com sua obrigação legal e ambiental de averbar a reserva legal na matrícula do imóvel, merece aplausos a conclusão a que chegou o Colégio Registral Imobiliário de Santa Catarina63, de que "não há necessidade de demonstração de registro perante o CAR, caso já conste averbação de reserva legal na matrícula. Fundamento: já houve especialização e o artigo 30 do Novo Código Florestal busca a alimentação do banco de dados do CAR com as especializações já realizadas".

\section{CONSIDERAÇÕES FINAIS}

"A noção de desenvolvimento sustentável implica a necessária redefinição das relações sociedade humana-natureza e, portanto, em uma mudança substancial

61 TJSP. PROVIMENTO CG N.o 36/2013, Publicado em 08/11/2013. Disponível em: http://iregistradores.org.br/noticias/tjsp-publicado-provimento-cg-n-362013-acrescenta-itens-aocapitulo-xx-das-normas-de-servico-da-corregedoria-geral-da-justica/, acesso em 29/09/2014.

62 TJSP. PROVIMENTO CG N.0 36/2013, Publicado em 08/11/2013. Disponível em: http://iregistradores.org.br/noticias/tjsp-publicado-provimento-cg-n-362013-acrescenta-itens-aocapitulo-xx-das-normas-de-servico-da-corregedoria-geral-da-justica/, acesso em 29/09/2014.

63 Externada por meio do Ofício n. 15/2014, datado de 12/09/2014, endereçado ao ViceCorregedor Geral de Justiça do c. TJSC. 
D'ÁVILA, Gilmara Vanderlinde Medeiros. Averbação da reserva legal x Cadastro ambiental rural, avanço ou retrocesso?. Revista Eletrônica Direito e Política, Programa de Pós-Graduação Stricto Sensu em Ciência Jurídica da UNIVALI, Itajaí, v.10, n.1, edição especial de 2015. Disponível em: www.univali.br/direitoepolitica - ISSN 1980-7791.

do próprio processo civilizatório". ${ }^{64}$

"A busca da sustentabilidade é um processo em construção, uma tarefa que envolve várias dimensões e tempo. E que exige urna conscientização crescente e profunda dos problemas da natureza e sua relação com o homem". ${ }^{65}$

"Desenvolvimento sustentável, portanto, não é um estado, mas uma referência para processos que possam anunciar uma transição desta para uma nova sociedade." 66

Na vigência do antigo Código Florestal era obrigatória a averbação da reserva legal na matrícula do imóvel, devidamente embasada em documentos emitidos pelo órgão fiscal, a quem competia fazer a prévia analise e aprovação, embasado em mapas e memoriais necessariamente confeccionados por profissional legalmente habilitado e sob a sua responsabilidade e ainda, contando com o crivo do registrador de imóveis, profissional de direito, delegado do poder público, a quem competia verificar a documentação e o cumprimento aos requisitos legais de implementação, bem como, aos requisitos da correta especialidade objetiva e subjetiva para que fosse procedida à averbação.

No novo Código Florestal tudo isso foi deixado de lado, flexibilizando-se as normas de proteção ambiental, não mais se exigindo que o procedimento seja feito por profissional qualificado - pequeno proprietário pode preencher sozinho o cadastro - em franco retrocesso da proteção ambiental e em detrimento do princípio da informação, pois esta importante informação ambiental - existência e localização da reserva legal - não estará mais na matrícula do imóvel, sendo mera faculdade a averbação.

Desde a implementação da obrigatoriedade da averbação da reserva legal na matrícula do imóvel, foram inúmeras as prorrogações nos prazos, o que

64 DEMAJOROVIC, Jacques. Sociedade de risco e responsabilidade socioambiental Perspectivas para a educação corporativa. São Paulo: Senac, 2003, p. 10.

65 ALBUQUERQUE, José de Lima. Gestão Ambiental e Responsabilidade Social: conceitos, ferramentas e aplicações. São Paulo: Atlas. 2009, p. 21.

${ }^{66}$ ALBUQUERQUE, José de Lima. Gestão Ambiental e Responsabilidade Social: conceitos, ferramentas e aplicações. 2009, p. 21. 
D'ÁVILA, Gilmara Vanderlinde Medeiros. Averbação da reserva legal x Cadastro ambiental rural, avanço ou retrocesso?. Revista Eletrônica Direito e Política, Programa de Pós-Graduação Stricto Sensu em Ciência Jurídica da UNIVALI, Itajaí, v.10, n.1, edição especial de 2015. Disponível em: www.univali.br/direitoepolitica - ISSN 1980-7791.

contribuiu muito para a sensação, a nosso ver falsa, de que a averbação na matrícula do imóvel não era eficaz e/ou de que era procedimento apenas burocrático.

A averbação só não foi eficaz pelo motivo de que o próprio Poder Público tratou de torna-la ineficaz, prorrogando prazos de sua obrigatoriedade, não fiscalizando, não punindo e não disponibilizando número razoável de servidores para analisar os pedidos de delimitação e aprovação (atrasando sobremaneira os processos).

Registra-se que o CAR terá o mesmo destino, caso sejam prorrogados os prazos de cobrança da inscrição e não sejam feitas as competentes e tempestivas fiscalizações ou pior ainda, como o CAR - diferente da averbação da reserva, que necessitava de prévia avaliação do órgão ambiental para ser aprovada - pode ser preenchido por leigos, sem o menor conhecimento técnico, sendo que a demora na manifestação do órgão ensejará a validade temporária dos cadastros $^{67}$, o que certamente gerará completa insegurança ambiental, praticamente anulando a proteção visada pelo instituto da reserva legal.

Por todo o exposto, chega-se a conclusão de que o CAR representará avanço em alguns pontos - caso realmente venham a ser implementadas, na prática, suas promessas: a obtenção de crédito agrícola, com juros menores; limites e prazos maiores que os praticados no mercado; a contratação do seguro agrícola em condições melhores que as normalmente existentes no mercado; e linhas de financiamento especiais visando atender iniciativas de preservação voluntária de vegetação nativa, proteção de espécies da flora nativa ameaçadas de extinção, manejo florestal e agroflorestal sustentável, dentre outras - mas também representa retrocesso em outros, o que na área ambiental é imperdoável, pois trata-se de direito indisponível, a exemplo da revogação da obrigatoriedade de averbação da reserva legal na matrícula do imóvel, da dispensabilidade da informação de dados da reserva e ambientais ser prestada por meio de profissional legalmente habilitado, com validação do órgão ambiental póstuma.

${ }^{67}$ conforme artigo $2^{\circ}$. do Decreto $7.830 / 12$. 
D'ÁVILA, Gilmara Vanderlinde Medeiros. Averbação da reserva legal x Cadastro ambiental rural, avanço ou retrocesso?. Revista Eletrônica Direito e Política, Programa de Pós-Graduação Stricto Sensu em Ciência Jurídica da UNIVALI, Itajaí, v.10, n.1, edição especial de 2015. Disponível em: www.univali.br/direitoepolitica - ISSN 1980-7791.

\section{REFERÊNCIA DAS FONTES CITADAS:}

ALBUQUERQUE, José de Lima. Gestão Ambiental e Responsabilidade Social: conceitos, ferramentas e aplicações. São Paulo: Atlas. 2009.

ARAGÃO, Alexandra. Direito constitucional do ambiente da União Européia. In: CANOTILHO, José Joaquim Gomes; LEITE, José Rubens Morato (orgs.). Direito Constitucional Ambiental Brasileiro. São Paulo: Saraiva, 2007, 433 p, pp. 11-55.

BALBINO FILHO. Nicolau. Registro de Imóveis. São Paulo: Saraiva, 9a. Edição, 1999.

BRASIL. Presidência da República. CONSTITUIÇÃo DA REPÚBLICA FEDERATIVA DO BRASIL DE 1988. Publicada no DOU DE 5.10.1988. Disponível em: http://www.planalto.gov.br/ccivil_03/constituicao /constituicaocompilado.htm , acesso em 18/11/2013.

BRASIL. Presidência da República. Lei n. 4.771, de 15 de setembro de 1965. Institui o Código Florestal. Publicada no D.O.U de 16.9.1965. Disponível em: https://www.planalto.gov.br/ccivil_03/LEIS/L4771.htm, acesso em 29/09/2014.

BRASIL. Presidência da República. Lei no 6.015, de 31 de dezembro de 1973. Dispõe sobre os registros públicos, e dá outras providências. Publicada no DOU de 31.12.1973. Disponível em: http://www.planalto.gov.br/ccivil_03/leis/I6015.htm , acesso em 19/11/2013.

BRASIL. Presidência da República. Lei n. 6.938, de 31 de agosto de 1981. Dispõe sobre a Política Nacional do Meio Ambiente, seus fins e mecanismos de formulação e aplicação, e dá outras providências. Publicado no DOU de 2.9.1981. Disponível em: http://www.planalto.gov.br/ccivil_03/leis/l6938.htm , acesso em 29/09/2014.

BRASIL. Presidência da República. Lei no 8.935, de 18 de novembro de 1994. Regulamenta o art. 236 da Constituição Federal, dispondo sobre serviços notariais e de registro. Publicada no DOU de 21.11.1994. Disponível em: http://www.planalto.gov.br/ccivil_03/leis//8935.htm, acesso em 29/09/2014.

BRASIL. Presidência da República. Lei 10.406, de 10 de janeiro de 2002. Institui o Código Civil. Publicado no DOU de 11.1.2002. Disponível em: http: //www.planalto.gov.br/ccivil_03/leis/2002/l10406.htm, acesso em 29/09/2014.

BRASIL. Presidência da República. Lei 12.651 de 25 de maio de 2012. Publicada no DOU DE 28.05.2012. Disponível em: http://www.planalto.gov.br/ccivil_03/_Ato2011-2014/2012/Lei/L12651.htm, acesso em 29/09/2014.

BRASIL. Presidência da República. Ministério do Meio Ambiente. http://www.mma.gov.br/desenvolvimento-rural/cadastro-ambiental-rural, acesso 
D'ÁVILA, Gilmara Vanderlinde Medeiros. Averbação da reserva legal x Cadastro ambiental rural, avanço ou retrocesso?. Revista Eletrônica Direito e Política, Programa de Pós-Graduação Stricto Sensu em Ciência Jurídica da UNIVALI, Itajaí, v.10, n.1, edição especial de 2015. Disponível em: www.univali.br/direitoepolitica - ISSN 1980-7791.

em 25/09/2014.

CAMARGO, Flavia. Os rumos do cadastro ambiental precisam mudar. Disponível em: http://www.socioambiental.org/pt-br/blog/blog-do-ppds/osrumos-do-cadastro-ambiental-rural-car-precisam-mudar, acesso em 25/09/2014.

CANOTILHO, José Joaquim Gomes. Direito Constitucional e Teoria da Constituição. 3 ed. Coimbra: Almedina, 1999.

CAVEDON, Fernanda de Salles. Função Social e Ambiental da Propriedade. Florianópolis: Visualbooks, 2003.

CRUZ, Paulo Márcio. Globalização, transnacionalidade e sustentabilidade [recurso eletrônico] /Paulo Márcio Cruz, Zenildo Bodnar ; participação especial Gabriel Real Ferrer ; org. e rev. Lucas de Melo Prado. - Dados eletrônicos. - Itajaí : UNIVALI, 2012.

DEMAJOROVIC, Jacques. Sociedade de risco e responsabilidade socioambiental - Perspectivas para a educação corporativa. São Paulo: Senac, 2003.

DIP, Ricardo e JACOMINO, Sérgio. (Org.) Propriedade e direitos reais limitados. São Paulo: Revista dos Tribunais, 2012, v. 5.

FENSTERSEIFER, Tiago. Direitos fundamentais e proteção do ambiente: a dimensão ecológica da dignidade humana no marco jurídico constitucional do estado socioambiental de direito. Porto Alegre: Livraria do Advogado Editora, 2008, p. 159.

MACHADO, Paulo Affonso Leme. Direito Ambiental Brasileiro. 12. ed. São Paulo: Malheiros, 2004.

PASOLD, Cesar Luiz. Prática da Pesquisa Jurídica - idéias e ferramentas úteis ao Pesquisador do Direito. 9 ed. Florianópolis:OAB-SC Editora co-edição OAB Editora, 2003.

SANTA CATARINA. Lei no 5.793, de 16 de outubro de 1980 . Governo do Estado de Santa Catarina. Dispõe sobre a proteção e melhoria da qualidade ambiental e dá outras providências. Publicada no DO de 22/10/1980. Disponível em: http://200.192.66.20/alesc/PesquisaDocumentos.asp, acesso em $19 / 11 / 2013$.

SARLET, Ingo Wolfgang. A eficacia dos direitos fundamentais. 5a. ed. Porto Alegre: Livraria do Advogado, 2005.

FENSTERSEIFER, Tiago. Direito Constitucional Ambiental: constituição, direitos fundamentais e proteção do ambiente. 3a. ed. Rev. Atual. E ampli.. São Paulo: Revista dos Tribunais, 2013.

SILVA, José Afonso da. Direito Ambiental Constitucional. 9a. Edição, São 
D'ÁVILA, Gilmara Vanderlinde Medeiros. Averbação da reserva legal x Cadastro ambiental rural, avanço ou retrocesso?. Revista Eletrônica Direito e Política, Programa de Pós-Graduação Stricto Sensu em Ciência Jurídica da UNIVALI, Itajaí, v.10, n.1, edição especial de 2015. Disponível em: www.univali.br/direitoepolitica - ISSN 1980-7791.

Paulo, Malheiros Editores, 2011.

VILARINHO, Renata. ÁREAS DE PRESERVAÇÃo. Cadastro Ambiental Rural traz a tão esperada simplificação. Disponível em: http://www.conjur.com.br/2014mai-14/renata-vilarinho-cadastro-ambiental-rural-traz-tao-esperadasimplificacao, acesso em 25/09/2014.

Submetido em: Setembro/2014

Aprovado em: Outubro/2014 